\title{
Giant cells in temporal artery biopsies are associated with a reduced risk of large vessel involvement in patients with giant cell arteritis : a retrospective cohort study
}

\author{
Nazanin Naderi \\ Lund University \\ Aladdin Mohammad \\ Lund University \\ Karin Wadström \\ Lund University \\ Minna Willim \\ Lund University \\ Jan-Åke Nilsson \\ Lund University
}

Carl Turesson ( $\sim$ Carl.Turesson@med.lu.se )

Lund University https://orcid.org/0000-0002-3805-2290

\section{Research article}

Keywords: Giant cell arteritis, large vessel vasculitis, extracranial giant cell arteritis, temporal artery biopsy, predictors

Posted Date: November 12th, 2020

DOl: https://doi.org/10.21203/rs.3.rs-103583/v1

License: (a) (i) This work is licensed under a Creative Commons Attribution 4.0 International License. Read Full License 


\section{Abstract}

Background: Giant cell arteritis (GCA) is a systemic disease with extensive vascular involvement. There is limited and conflicting information on the relation between patient characteristics at diagnosis and future disease phenotypes. We aimed to investigate predictors of time dependent large vessel involvement (LVI) in a population-based cohort of patients with GCA.

Methods: GCA patients with positive temporal artery biopsies (TAB) between 1997and 2010 were identified through a regional pathology register. A structured review of histopathology reports and relevant imaging studies was performed. Cases with LVI through July 2016 were identified. Patients were followed to first LVI, death, migration from the area or July 29, 2016. Event free survival by clinical and histopathologic features was estimated using the Kaplan-Meier method. Potential predictors of LVI were examined using Cox regression models.

Results: A total of 274 patients were included. The mean age at GCA diagnosis was 75.7 years. Fifty-one patients (19\%) had documented LVI during the follow-up, corresponding to an incidence rate of 2.4/100 person-years. The median time from GCA diagnosis to the diagnosis of LVI was 4.5 years (interquartile range $0.6-7.4)$. Thirty-four patients had aortic involvement ( $67 \%$ of those with $L V l ; 12 \%$ of all GCA cases). Survival free of LVI was longer in patients with giant cells in the TAB $\left(75^{\text {th }}\right.$ percentile 14.0 vs 6.7 years; $p=0.014)$. In age-adjusted analysis, the presence of giant cells in the TAB was associated with reduced risk of LVI (hazard ratio $0.48 ; 95 \%$ confidence interval 0.27-0.86).

Conclusions: The negative association with giant cells in the TAB suggests that patients with LVI constitute a subset of GCA with particular disease mechanisms. This underlines the heterogeneity of GCA, which should be further explored in prospective studies.

\section{Key Messages}

1. During follow-up of biopsy-proven GCA patients, large vessel involvement was detected in $19 \%$.

2. Patients with giant cells in the biopsy had reduced risk of large vessel involvement.

\section{Introduction}

Giant cell arteritis (GCA) is the most frequent systemic vasculitis in the population over the age of 50 in western countries, with incidence estimates of 14-33/100 000 in Scandinavian populations $[1,2]$. The disease was first described in 1889 [3] in its most classical form. Temporal artery biopsy (TAB) is the gold standard for diagnosing GCA. The first biopsy was performed in 1931 [4]. In the biopsy the presence of giant cells, granuloma, disrupted internal elastic lamina, thickened intima and presence of inflammatory cells are indicative of the disease.

Since the first description other disease subsets have been recognized [5-7]. The subsets can be defined according to clinical phenotypes, imaging findings, histopathology or laboratory findings [8]. Although 
there is no consensus, the most common way of subgrouping patients with GCA is by the clinical phenotypes. classic cranial arteritis (with or without polymyalgia rheumatica (PMR)), GCA with extracranial large vessel involvement (LVI), occult GCA with mainly constitutional symptoms (e.g. inflammation and/or fever of unknown origin), and clinical pure PMR with underlying subclinical vasculitis [9].

Although different subsets show different clinical course and prognosis [5, 10-15], there are still no established predictors for LVI. Results are divergent on the relation between LVI and presence of cranial symptoms [5, 7, 11, 16-21], PMR at the time of diagnosis [5, 10,11, 13, 16, 18, 21, 22], level of systemic inflammatory markers and leucocyte count $[5,7,10,11,13,18,19,22-25]$ and tobacco usage $[16,18]$.

Several studies have found that patients with LVI are younger than other GCA patients at the time of disease onset $[5,16,17,26]$. In a recent retrospective multicenter study in which LVI was identified in $45 \%$ of patients with GCA, the proportion of patients under 70 years in the LVI group was $60 \%$ compared to $27 \%$ in patients without LVI. Conversely, the proportion of patients over 80 years were $9 \%$ and $26 \%$, respectively, in these groups [16]. Most studies indicate that female sex is a risk factor for LVI in GCA [5, $16,17,26]$.

Arterial bruit, decreased peripheral pulse, discrepancy between arm blood pressures, extremity claudication, Raynaud's phenomenon and aortic valve insufficiency are all signs and symptoms that may be due to $\mathrm{LVI}$, and have been associated with subsequent imaging findings in several studies $[5,10,16$, $18,23,26]$.

Different histopathological patterns occurring in GCA and their clinical correlation have been studied [2732]. Giant cells are reported in TAB specimens of patients with GCA with varying frequency, ranging from 37 to $84 \%[27,29-38]$. Analyses of the association between the presence of giant cells and different clinical manifestations have generated conflicting results. We have previously investigated the predictive value of different histopathologic features of TAB for LVI, and found a negative association with the presence of giant cells in the histopathological reports [22]. To our knowledge, this was the first study to examine this relationship in patients with biopsy-proven GCA. The present study was undertaken to further investigate predictors for LVI in a larger cohort of patients with biopsy-proven GCA, and, specifically, to assess the relation between baseline characteristics and time to LVI.

\section{Material And Methods}

\section{Patients}

For identification of patients with biopsy-proven GCA, the database of the Department of Clinical Pathology in the county of Skåne (population 1243329 on December 2010) was used. Patients with positive TABs performed between 1997 and 2010 who were diagnosed with GCA ( $N=840)$ were identified, as previously described [39]. Among these, patients from two defined areas of the county that had previously been included in two clinical studies $[22,40]$ were pooled for the present analysis (Fig. 1). 
Subcohort I consisted of patients from the regional cohort, registered at the pathology unit in Kristianstad (one of four units contributing to the database). These have previously been reported in a retrospective study of large vessel involvement and associated factors [22]

Subcohort II consisted of patients from the regional cohort living in the City of Malmö that had been included in a study of associations between clinical characteristics, glucocorticosteroid treatment and TAB findings [40]. The patients had a registered diagnosis of GCA after participation in two populationbased surveys, the Malmö Diet and Cancer Study (MDCS) [41] and the Malmö Preventive Medicine Project (MPMP) [42], previously identified in a study investigating predictors of GCA [43] or had been diagnosed with GCA at Malmö University Hospital within the same time frame.

\section{Data collection}

The process of data collection has been described previously in detail $[22,43]$. The structured review of medical records and histopathology reports of all the identified patients included data extraction of items of the 1990 American College of Rheumatology classification criteria for GCA [44]. In addition, other clinical data at the time of diagnosis have been collected, e.g. previous PMR diagnosis, PMR at the time of disease onset, laboratory results, initial dose of glucocorticosteroids, visual symptoms and permanent visual impairment related to GCA at diagnosis and during the follow-up were also recorded.

All but 18 of the histopathology reports could be retrieved and reviewed and the presence or absence of giant cells, granuloma, thrombus, fragmented internal elastic lamina (IEL), inflammatory infiltrates, fibrosis, and luminal stenosis was noted. If they were not mentioned in the report, they were considered absent.

With regard to imaging studies, the patients included were evaluated according to the clinical practice; there was no specified protocol for systematic vascular evaluation during the study period. The reports of all relevant radiological and clinical-physiological studies in patients with GCA were reviewed by one of the authors (NN). LVI was defined as presence of aneurysm, ectasia, or stenosis of the aorta and/or its main branches or positive ${ }^{18}$ fluoro-2-deoxy-d-glucose positron emission tomography-computed tomography $\left({ }^{18} \mathrm{FDG}\right.$ PET-CT) as assessed by the radiologist. Aneurysm was defined as reported aortic dilatation with a loss of wall parallelism and a recorded diameter of $\geq 30 \mathrm{~mm}$. Aortic ectasia was defined as reported abnormal dilatation without loss of wall parallelism.

Patients with detected LVI before diagnosis of GCA were excluded. For the present study, dates of death and migration from the study area were retrieved from a regional health care register.

\section{Statistics}

Patients were followed from date of GCA diagnosis and were censored at the date of: when LVI was first detected, death, migration from the area or the end of the study (i.e. date of last chart review, July 29, 2016). Event free survival, by baseline clinical characteristics (female sex, PMR symptoms at onset, preexisting PMR, visual symptoms at onset, and TAB findings - i.e. inflammatory cells, giant cells, 
granuloma, disrupted IEL, fibrosis and luminal stenosis), was estimated using the Kaplan-Meier method. Potential predictors of LVI were also examined using Cox regression analysis (covariates investigated: age at disease onset, female sex, PMR at onset, pre-existing PMR, visual symptoms at onset, erythrocyte sedimentation rate (ESR), C-reactive protein (CRP), platelet count (PIt), and TAB findings - i.e. inflammatory cells, giant cells, granuloma, disrupted IEL, fibrosis and luminal stenosis). For continuous variables, hazard ratios (HRs) were estimated per standard deviation (SD), and, in the case of Plt and CRP, also per quartile, using the lowest as reference. Furthermore, the risk of LVI in those aged $<70$ years and those aged 70-80 years was compared to those above 80 at GCA diagnosis (reference category). Covariates with $p<0.20$ in the bivariate analyses were included in multivariate models.

\section{Results}

\section{The GCA cohort}

A total of 286 patients with biopsy-proven GCA were identified from the two subcohorts. Twelve patients with LVI before GCA diagnosis were excluded, leaving a study sample of 274 . Mean age at diagnosis was 75.7 years [SD 8.09; range 49.5-94.8years]. $76.6 \%$ were females. Twenty-four (16\%) of those with available information on previous medical history had a pre-existing diagnosis of PMR. At onset of GCA, $23 \%$ had current PMR symptoms, and $36 \%$ had visual symptoms. Demographics and clinical characteristics, overall and by LVI, are presented in Table 1. Time on GC treatment before TAB was similar in patients with and without LVI (Table 1). 
Table 1

Baseline demographic and clinical characteristics for GCA patients, overall and by Large Vessel Involvement (LVI)

\begin{tabular}{|c|c|c|c|}
\hline & $\begin{array}{l}\text { All patients } \\
\mathrm{n}=\mathbf{2 7 4}\end{array}$ & $\begin{array}{l}\text { LVI } \\
n=51\end{array}$ & $\begin{array}{l}\text { No LVI } \\
n=223\end{array}$ \\
\hline Female sex, $\mathrm{n}(\%)$ & $210(76.6)$ & $39(75.0)$ & $169(76.8)$ \\
\hline Age at onset (years), mean (SD) & $75.7(8.1)$ & $72.9(8.4)$ & $76.3(7.9)$ \\
\hline$<70$ (years), $\mathrm{n}(\%)$ & $67(24.5)$ & $19(37.3)$ & $48(21.5)$ \\
\hline $70-80$ (years), n (\%) & $118(43.1)$ & $21(41.2)$ & $97(43.5)$ \\
\hline$>80$ (years), n (\%) & $89(32.5)$ & $11(21.6)$ & $78(35.0)$ \\
\hline Pre-existing PMR, n (\%) & $24(8.8)$ & $6(11.5)$ & $18(8.2)$ \\
\hline PMR symptoms at onset, $\mathrm{n}(\%)$ & $60(22.9)$ & $12(23.1)$ & $47(21.4)$ \\
\hline Visual symptoms at onset, n (\%) & $94(35.9)$ & $19(36.5)$ & $76(34.5)$ \\
\hline Permanent visual impairment, $\mathrm{n}(\%)$ & $32(12.4)$ & $3(5.8)$ & $29(13.2)$ \\
\hline Total visual loss, n (\%) & $11(4.2)$ & 0 & $11(5.0)$ \\
\hline $\operatorname{ESR}(\mathrm{mm} / \mathrm{h})$, mean $(\mathrm{SD})$ & $77(28)$ & $76(30)$ & $77(28)$ \\
\hline CRP (mg/L), median (SD) [IQR] & $94(73)[54 ; 141]$ & $80(57)[48 ; 132]$ & 95 (76) [56;144] \\
\hline Plt $\left(\times 10^{9} / \mathrm{L}\right)$, mean $(\mathrm{SD})$ & $420(137)$ & $442(132)$ & $414(138)$ \\
\hline Initial GC dose, median (SD) [IQR] & $50(33)[40 ; 60]$ & $52(15)[40 ; 60]$ & $50(36)[40 ; 60]$ \\
\hline Days on GC before biopsy, median [IQR] & $2.5[0.0 ; 2.5]$ & $2.0[0.0 ; 2.0]$ & $3.0[0.0 ; 3.0]$ \\
\hline IV GC treated, n (\%) & $19(7.4)$ & $3(6.4)$ & $16(7.6)$ \\
\hline ACR 1990 criteria, n (\%) & $253(97.3)$ & $47(95.9)$ & $206(97.6)$ \\
\hline \multicolumn{4}{|l|}{ Histopathology findings } \\
\hline Inflammatory infiltration, $\mathrm{n}(\%)$ & $246(96.1)$ & $47(95.9)$ & $199(96.1)$ \\
\hline Giant cells, $n(\%)$ & $138(53.9)$ & $21(42.9)$ & $117(56.5)$ \\
\hline
\end{tabular}

LVI: large vessel involvement; SD: Standard deviation; IQR: interquartile range; PMR: polymyalgia rheumatica; ESR: Erythrocyte sedimentation rate; CRP: C-reactive protein; Plt: platelets; $\mathrm{Hb}$ : haemoglobin; GC: glucocorticoid; IV: intravenous; IEL: internal elastic lamina; AMI: acute myocardial infarction; CVI/TIA: Cerebral vascular incident/transient ischemic attack;

Normal values: for ESR: Men $\geq 60$ years $\leq 24 \mathrm{~mm} / 1 \mathrm{~h}$, Women $>50$ years $\leq 35 \mathrm{~mm} / 1 \mathrm{~h}$; for CRP: initially $9 \mathrm{mg} / \mathrm{L}$, later $<3$.

Missing data: for PMR signs/symptoms: $\mathrm{n}=12$, for ESR: $\mathrm{n}=25$, for CRP: $\mathrm{n}=44$, for Plt: $\mathrm{n}=88$. 


\begin{tabular}{|c|c|c|c|}
\hline & $\begin{array}{l}\text { All patients } \\
n=274\end{array}$ & $\begin{array}{l}\text { LVI } \\
\mathrm{n}=51\end{array}$ & $\begin{array}{l}\text { No LVI } \\
n=223\end{array}$ \\
\hline Granuloma & $37(14.5)$ & $9(18.4)$ & $28(13.5)$ \\
\hline Disrupted IEL, n (\%) & $156(60.9)$ & $32(65.3)$ & $124(59.9)$ \\
\hline Fibrosis, n (\%) & $56(21.9)$ & $10(20.4)$ & $46(22.2)$ \\
\hline Luminal stenosis, n (\%) & $84(60.4)$ & $19(63.3)$ & $65(59.6)$ \\
\hline \multicolumn{4}{|c|}{$\begin{array}{l}\text { LVI: large vessel involvement; SD: Standard deviation; IQR: interquartile range; PMR: polymyalgia } \\
\text { rheumatica; ESR: Erythrocyte sedimentation rate; CRP: C-reactive protein; Plt: platelets; Hb: } \\
\text { haemoglobin; GC: glucocorticoid; IV: intravenous; IEL: internal elastic lamina; AMI: acute myocardial } \\
\text { infarction; CVI/TIA: Cerebral vascular incident/transient ischemic attack; }\end{array}$} \\
\hline \multicolumn{4}{|c|}{$\begin{array}{l}\text { Normal values: for ESR: Men } \geq 60 \text { years } \leq 24 \mathrm{~mm} / 1 \mathrm{~h} \text {, Women }>50 \text { years } \leq 35 \mathrm{~mm} / 1 \mathrm{~h} \text {; for CRP: } \\
\text { initially } 9 \mathrm{mg} / \mathrm{L} \text {, later }<3 \text {. }\end{array}$} \\
\hline
\end{tabular}

\section{Large vessel involvement}

Fifty-one (19\%) had evidence of LVI after GCA diagnosis. Among these, $26(51 \%)$ had isolated aortic involvement, $17(33 \%)$ isolated tributary involvement and the remaining $8(16 \%)$ patients had a combination of both. The median GCA duration prior to detection of LVI was 4.5 years (interquartile range $0.6-7.4)$.

Patients were followed for 2137 person-years after GCA diagnosis. Accordingly the incidence rate of LVI was $2.4 / 100$ person-years $(95 \% \mathrm{Cl}[1.7,3.0]$ of follow up, and was similar among males $(2.4 / 100$ personyears, $95 \% \mathrm{Cl}[1.1,3.7])$ and females $(2.4 / 100$ person-years, $95 \% \mathrm{Cl}[1.6,3.1])$.

The vascular imaging modalities used to detect LVI are listed in Supplementary Table 1.

of abdomen and echocardiography; PET: positron-emission tomography; CT: computed tomography.

\section{Distribution of the affected large vessels}

Aortic ectasia was found in 20 patients (ascendens $n=10$, descendens $n=4$, abdominal $n=6$ ). In one patient, the whole aorta was ectatic and in four others the aorta had both aneurysmatic and ectatic changes. A total of 19 aortic aneurysms (ascendens $n=13$, descendens $n=1$, abdominal $n=5$ ) were found in 19 patients. Two patients had dissections, one ascending aorta aneurysm with type-A dissection and one type-B dissection without aneurysm.

Involvement of 39 tributary arteries was found in 25 cases, including 31 stenotic arteries (carotid $n=7$, subclavian $n=2$, coeliac $n=2$, superior mesenteric $n=2$, renal $n=2$, iliac $n=4$, femoral $n=7$, distal lower extremity $n=5$, intracranial $n=2$ ) and 6 aneurysmatic arteries (carotid $n=1$, innominate $n=1$, coeliac $n=$ 1 , iliac $n=3$ ) and one subclavian artery with signs of vasculitis on PET. 
The distribution and type of vessel involvement in the fifty-one patients with LVI are depicted in Fig. 1.

\section{Predictors of LVI - Survival by baseline features and Cox regression}

\section{Demographics:}

There was no difference in survival time free of LVI between females and males (Table 2). The proportion of patients with onset of GCA at 70 years or younger was higher among those with LVI (37.3\% vs $21.5 \%$ ). There was a trend towards reduced risk of LVI with increasing age at GCA onset (HR 0.82 per SD; CI 95\% $0.61,1.09$ ). Compared to those aged $>80$ at GCA diagnosis, there was a greater risk of LVI in those diagnosed with GCA when they were younger than 70 years (HR 2.29; 95\% Cl 1.00, 5.25).

\section{Clinical features \& laboratory parameters:}

Clinical features such as visual symptoms, inflammatory laboratory tests at diagnosis (ESR, CRP, PIt) or symptoms of PMR (pre-existing or current) did not affect the risk of future LVI (Table 3 and Table 4). Among those who developed LVI, fewer suffered from permanent visual impairment or total visual loss, (Table 1), although numbers were too small for meaningful time dependent analyses.

\section{Histopathology features:}

Survival free of LVI was significantly longer in patients with giant cells present in the TAB, 75th percentile 14.0 vs 6.7 years ( $p=0.01$; Table 2 and Fig. 3 ). Other histopathology features had no impact on the LVIrisk (Tables 2 and 3 ).

The presence of giant cells in the TAB was associated with a reduced risk of LVI in bivariate Cox regression (Table 3 ) as well as in multivariate analysis, adjusted for age (HR: $0.48 ; 95 \% \mathrm{Cl} 0.27,0.86$ ). 
Table 2

Survival time free of LVI, 75th percentile (years; Kaplan-Meier analysis)

\begin{tabular}{|lccl|}
\hline & Present & Absent & p (Breslow) \\
\hline Female sex & 12.9 & 13.1 & 0.96 \\
\hline PMR symptoms at onset & 11.7 & 13.7 & 0.98 \\
\hline Pre-existing PMR & 10.1 & 11.7 & 0.83 \\
\hline Visual symptoms at onset & 11.7 & 13.7 & 0.64 \\
\hline Giant cells & 14.0 & 6.7 & 0.01 \\
\hline Granuloma & 8.5 & 11.7 & 0.83 \\
\hline Disrupted IEL & 9.7 & 14.0 & 0.56 \\
\hline Fibrosis & 12.9 & 10.1 & 0.67 \\
\hline Luminal stenosis & 10.3 & 10.1 & 0.90 \\
\hline PMR: polymyalgia rheumatica; IEL: internal elastic lamina. \\
\hline
\end{tabular}


Table 3

Predictors for LVI in GCA; unadjusted

\begin{tabular}{|c|c|c|}
\hline & HR & $95 \% \mathrm{Cl}$ \\
\hline Age at disease onset (years) $<70$ & 2.29 & $1.00-5.25$ \\
\hline $70-80$ & 1.5 & $0.72-3.21$ \\
\hline$>80$ & $1.00=$ ref & \\
\hline Age (year) (per SD) & 0.82 & $0.61-1.09$ \\
\hline Female sex & 1.01 & $0.54-1.90$ \\
\hline PMR at onset & 0.89 & $0.46-1.71$ \\
\hline Pre-existing PMR & 0.85 & $0.35-2.09$ \\
\hline Visual symptoms at onset & 0.87 & $0.48-1.56$ \\
\hline ESR $(\mathrm{mm} / \mathrm{h})($ per SD) & 0.98 & $0.73-1.31$ \\
\hline CRP (mg/L), (per SD) & 0.82 & $0.58-1.16$ \\
\hline CRP (per quartile), lowest $\leq 54$ (mg/L), & $1.00=$ ref & \\
\hline Quartile 2 54.1-94 & 0.50 & $0.21-1.16$ \\
\hline Quartile 3 94.1-141.25 & 0.86 & $0.41-1.79$ \\
\hline Quartile $4>141.25$ & 0.53 & $0.23-1.24$ \\
\hline Plt $\left(\times 10^{9} / \mathrm{L}\right)$ per SD & 1.18 & $0.86-1.61$ \\
\hline Plt (per quartile), lowest $\leq 319\left(\times 10^{9} / \mathrm{L}\right)$ & 1.00 = ref & \\
\hline Quartile 2 319.1-406 & 0.64 & $0.24-1.67$ \\
\hline Quartile 3 406.1-496 & 0.81 & $0.33-2.01$ \\
\hline Quartile $4>496$ & 0.90 & $0.37-2.15$ \\
\hline Giant cells & 0.49 & $0.28-0.87$ \\
\hline Granuloma & 1.19 & $0.58-2.45$ \\
\hline Disrupted IEL & 1.38 & $0.76-2.48$ \\
\hline Fibrosis & 0.85 & $0.42-1.70$ \\
\hline Luminal stenosis & 0.99 & $0.47-2.08$ \\
\hline
\end{tabular}




\section{Discussion}

In the present study, $19 \%$ of patients with biopsy-proven GCA had diagnosed LVI during the follow-up, corresponding to an incidence of 2.4/100 person-years of follow-up. We confirmed a negative association between the presence of giant cells in the TAB and subsequent development of LVI in patients with GCA. We also observed a trend toward reduced risk of LVI with increasing age at GCA-onset, in keeping with previous studies $[5,11,16,17,26]$. The shift towards onset of GCA below age 70 in the subgroup with LVI, with a corresponding reduction in the number of patients aged $>80$ years at diagnosis, is compatible with previous findings in a study that compared the same age categories [16]. The lower risk in elderly patients in the present study could be due to less extensive investigations with increasing age. On the other hand, in the other study with similar observations, all patients were scanned for LVI [16].

We did not observe an increased risk with elevated laboratory inflammatory markers.

Previously, a higher ESR was negatively associated with $\operatorname{LVI}$ in some studies $[5,18,23]$ but not in others $[7,10,11,13,19,22,24,25]$.

In accordance with some $[10,11]$, but in contrast to other studies $[5,16,17,26]$, there was no major difference between females and males in the occurrence of LVI in this study.

Previous studies indicate that cranial symptoms at the time of GCA diagnosis are negatively associated with $\operatorname{LVI}[5,7,11,16-20]$. In the present study, severe ocular involvement tended to be less frequent among those with LVI. Other types of cranial symptoms were not evaluated.

In contrast to our previous study of a smaller sample [22], we did not find any association between PMR symptoms at GCA diagnosis and subsequent LVI. Other previous studies of PMR as a risk factor have yielded divergent results: one reported a negative association with LVI [16], others showed no difference between the two groups $[5,10,13,18,19,21]$, one other study showed a higher proportion with PMR at GCA diagnosis in the LVI group [17] and one study found more patients with PMR prior to GCA diagnosis in the LVI group [11]. Differences in case selection, and in the ascertainment and management of PMR, may explain these discrepancies.

Histopathological features or patterns have been the subject of several studies of possible associations with specific clinical features or clinical course. Previous studies on clinical correlations with giant cells are summarized in Supplementary Table 2. The focus of these studies has been on cranial ischemic symptoms and signs, usually presence of headache/ocular and jaw manifestations, systemic manifestations and laboratory analysis in varying degrees. The number and type of histopathological features investigated also varied. Two studies found significant associations between the occurrence of giant cells and cranial ischemic complications $[32,36]$. Two other studies found a trend towards a higher occurrence of cranial ischemic complications in the group with giant cells compared to those without [37, 38]. 
Giant cells are fused macrophages, formed through interferon- $y$ (IFN- $\gamma$ ) stimulation [45]. These macrophages produce among others: reactive oxygen species, matrix metalloproteinases, platelet-derived growth factor and vascular endothelial growth factor [46]. IFN- $\gamma$ is produced by differentiated Th1 cells [46]. The differentiation is driven by interleukin 12 (IL-12) [46]. High levels of IL-12 [47] and IFN-y [48] are associated with more ischemic complications. It is possible that the LVI phenotype of GCA is less dominated by Th1 mechanisms considering less frequent presence of giant cells in the TAB, fewer cranial ischemic manifestations and the massive presence of artery tertiary lymphoid organs that lack macrophages [49].

Limitations of this study are related to the retrospective design. Data collection was limited to the recorded information in patient charts, and no standardized physical evaluation was performed. In contrast with other studies [16], we did not limit our analysis to patients that had been investigated with $\geq 1$ large vessel imaging scan. Imaging modalities during study period were heterogeneous, nonstructured and often performed due to other indications than suspected vasculitis. Therefore, the incidence of LVI and its extent is likely underestimated due to lack of systematic imaging studies. LVI detected in this study reflect the clinical practice of the time period. Based on the study design, we cannot rule out that some of the changes may be of atherosclerotic origin.

Strengths of this study include the population-based study design, the relatively large patient cohort with a long follow-up period, and the systematic review of pathology reports. Furthermore, we focused on objectively verified (biopsy-proven) GCA, which had an incidence in our population that was similar to other studies of Scandinavian populations $[2,50]$.

This study suggests that diverse disease mechanisms may be involved in GCA with different clinical presentation and disease progression. This could affect treatment response and raises the question of whether or not GCA should be treated differently based on phenotype and understanding of the underlying pathophysiology.

Future research should include prospective studies with structured imaging evaluations and standardized quantification of the giant cells and other histopathologic features in TABs.

In conclusion, in this study of patients with biopsy-positive GCA, LVI was detected in 1 in 5 patients during follow-up. There was a significantly lower risk of LVI in patients with giant cells in the biopsy. This may suggest particular disease mechanisms in LVI of GCA.

\section{Abbreviations}




\begin{tabular}{|ll|}
\hline Cl & Confidence interval \\
\hline CRP & C-reactive protein \\
\hline CT & Computed tomography \\
\hline CTA & Computed tomography angiography \\
\hline DSA & Digital subtraction angiography \\
\hline ESR & Erythrocyte sedimentation rate \\
\hline GCA & Giant cell arteritis \\
\hline HR & Hazard ratio \\
\hline IFN-Y & Interferon-Y \\
\hline IL-12 & Interleukin 12 \\
\hline IQR & Interquartile range \\
\hline LVI & Large vessel involvement \\
\hline MDCS & Malmö Diet and Cancer Study \\
\hline MPMP & Malmö Preventive Medicine Project \\
\hline MRA & Magnetic resonance angiography \\
\hline PET & Positron emissions tomography \\
\hline PMR & Polymyalgia rheumatica \\
\hline SD & Standard deviation \\
\hline TAB & Temporal artery biopsy \\
\hline Th1 & Thelper cell 1 \\
\hline
\end{tabular}

\section{Declarations}

Ethics approval and consent to participate:

Approved by the Regional Research Ethics Committee in Lund, Reference number 2010/517. No individual consent to participate was required by the Research Ethics Committee.

\section{Consent for publication}

Not applicable

Availability of data and materials 
The datasets generated and/or analysed during the current study are not publicly available due to Swedish legislation (the General Data Protection Regulation), but a limited and fully anonymised dataset containing the individual patient data that support the main analyses is available from the corresponding author on reasonable request.

\section{Competing interests: none}

\section{Funding}

This work was supported by The Swedish Research Council [grant number 2015-02228], The Swedish Rheumatism Association [grant numberR-759811] and Lund University [grant number ALFSKANE446501].

\section{Authors' contributions:}

NN participated in the data collection, statistical analysis and interpretation of the results, and wrote the first draft of the manuscript.

AM participated in the study design, data collection and interpretation of the results.

KW participated in the data collection and interpretation of the results.

MW assisted in data management and participated in the interpretation of the results.

JÅN assisted in the statistical analysis and participated in the interpretation of the results.

CT participated in the study design, the statistical analysis and the interpretation of the results, and helped draft the manuscript.

All authors read and approved the final manuscript.

\section{Acknowledgements}

none applicable

\section{References}

1. Haugeberg G, Paulsen PQ, Bie RB. Temporal arteritis in Vest Agder County in southern Norway: incidence and clinical findings. J Rheumatol 2000;27:2624-7.

2. Mohammad AJ, Nilsson J-Å, Jacobsson LTH, Merkel PA, Turesson C. Incidence and mortality rates of biopsy-proven giant cell arteritis in southern Sweden. Ann Rheum Dis 2015;74:993-7.

3. Hutchinson J. Diseases of the arteries: On a peculiar form of thrombotic arteritis of the aged which is sometimes productive of gangrene. Arch Surg (London) 1890;1:323-9. 
4. Horton BT, Magath TB, Brown GE. An undescribed form of arteritis of the temporal vessels. Mayo Clin Proc 1932;7:700-1.

5. Brack A, Martinez-Taboada V, Stanson A, Goronzy JJ, Weyand CM. Disease pattern in cranial and large-vessel giant cell arteritis. Arthritis Rheum 1999;42:311-317.

6. Förster S, Tato F, Weiss M, et al. Patterns of extracranial involvement in newly diagnosed giant cell arteritis assessed by physical examination, colour coded duplex sonography and FDG-PET. VASA 2011;40:219-27.

7. de Boysson H, Lambert M, Liozon E, et al. Giant-cell arteritis without cranial manifestations: Working diagnosis of a distinct disease pattern.

Medicine (Baltimore) 2016;95:e3818.

8. van der Geest KSM, Sandovici M, van Sleen Y, et al. What is the current evidence for disease subsets in giant cell arteritis? Arthritis Rheumatol 2018;70:1366-76.

9. Weyand CM, Goronzy JJ. Giant-cell arteritis and polymyalgia rheumatica. Ann Intern Med 2003;139:505-15.

10. Naderi N. Giant cell arteritis-a report on systematic physical evaluation and large vessel involvement as a prognostic risk factor for complicated disease course, real life data. Arch Gen Intern Med 2018;2:10-6.

11. Muratore F, Kermani TA, Crowson CS, et al. Large-vessel giant cell arteritis: a cohort study. Rheumatol Oxf Engl 2015;54:463-70.

12. Espitia O, Néel A, Leux C, et al. Giant cell arteritis with or without aortitis at diagnosis. A retrospective study of 22 patients with longterm followup. J Rheumatol 2012;39:2157-62.

13. Czihal M, Piller A, Schroettle A, et al. Impact of cranial and axillary/subclavian artery involvement by color duplex sonography on response to treatment in giant cell arteritis. J Vasc Surg 2015;61:1285-91.

14. Tatò F, Hoffmann U. Giant cell arteritis: a systemic vascular disease. Vasc Med Lond Engl 2008;13:127-40.

15. Both M, Ahmadi-Simab K, Reuter M, et al. MRI and FDG-PET in the assessment of inflammatory aortic arch syndrome in complicated courses of giant cell arteritis.

Ann Rheum Dis 2008;67:1030-3.

16. de Boysson $H$, Daumas $A$, Vautier $M$, et al. Large-vessel involvement and aortic dilation in giant-cell arteritis. A multicenter study of 549 patients. Autoimmun Rev 2018;17:391-8.

17. Czihal M, Zanker S, Rademacher $A$, et al. Sonographic and clinical pattern of extracranial and cranial giant cell arteritis. Scand J Rheumatol 2012;41:231-6.

18. Nuenninghoff DM, Hunder GG, Christianson TJH, McClelland RL, Matteson EL. Incidence and predictors of large-artery complication (aortic aneurysm, aortic dissection, and/or large-artery stenosis) in patients with giant cell arteritis: A population-based study over 50 years. Arthritis Rheum 2003;48:3522-3531. 
19. Prieto-González S, Arguis P, García-Martínez A, et al. Large vessel involvement in biopsy-proven giant cell arteritis: prospective study in 40 newly diagnosed patients using CT angiography. Ann Rheum Dis 2012;71:1170-6.

20. Schmidt WA, Krause A, Schicke B, Kuchenbecker J, Gromnica-Ihle E. Do temporal artery duplex ultrasound findings correlate with ophthalmic complications in giant cell arteritis? Rheumatol Oxf Engl 2009;48:383-5.

21. de Boysson H, Liozon E, Lambert M, et al. Giant-Cell Arteritis: Do we treat patients with large-vessel involvement differently? Am J Med 2017;130:992-5.

22. Naderi N, Mohammad AJ, Turesson C. Large vessel involvement in biopsy-proven giant cell arteritis: incidence, distribution, and predictors.

Scand J Rheumatol 2017;46:215-21.

23. Klein RG, Hunder GG, Stanson AW, Sheps SG. Large artery involvement in giant cell (temporal) arteritis. Ann Intern Med 1975;83:806-12.

24. Hamrin B. Polymyalgia arteritica. Acta Med Scand Suppl 1972;533:1-131.

25. Both M, Schulte K, Moosig F, et al. High white blood cell count in patients with giant cell arteritis predicts an increased risk of stenosis in upper extremity arteries.

Ann Rheum Dis 2011;70:1879-80.

26. Schmidt WA, Seifert A, Gromnica-Ihle E, Krause A, Natusch A. Ultrasound of proximal upper extremity arteries to increase the diagnostic yield in large-vessel giant cell arteritis. Rheumatology 2008;47:96101.

27. Hernández-Rodríguez J, Murgia G, Villar I, et al. Description and validation of histological patterns and proposal of a dynamic model of inflammatory infiltration in giant-cell arteritis. Medicine (Baltimore) 2016;95:e2368.

28. Cavazza A, Muratore F, Boiardi L, et al. Inflamed temporal artery: histologic findings in 354 biopsies, with clinical correlations. Am J Surg Pathol 2014;38:1360-70.

29. Breuer GS, Nesher R, Reinus K, Nesher G. Association between histological features in temporal artery biopsies and clinical features of patients with giant cell arteritis.

Isr Med Assoc J IMAJ 2013;15:339-42.

30. ter Borg EJ, Haanen HCM, Seldenrijk CA. Relationship between histological subtypes and clinical characteristics at presentation and outcome in biopsy-proven temporal arteritis. Identification of a relatively benign subgroup. Clin Rheumatol 2007;26:529-32.

31. Huston KA, Hunder GG, Lie JT, Kennedy RH, Elveback LR. Temporal arteritis: a 25-year epidemiologic, clinical, and pathologic study. Ann Intern Med 1978;88:162-7.

32. Chatelain D, Duhaut P, Schmidt J, et al. Pathological features of temporal arteries in patients with giant cell arteritis presenting with permanent visual loss.

Ann Rheum Dis 2009;68:84-8.

33. Mambo NC. Temporal (granulomatous) arteritis: a histopathological study of 32 cases. Histopathology 1979;3:209-21. 
34. Schmidt D, Löffler KU. Temporal arteritis. Comparison of histological and clinical findings. Acta Ophthalmol (Copenh) 1994;72:319-25.

35. Bevan AT, Dunnill MS, Harrison MJ. Clinical and biopsy findings in temporal arteritis. Ann Rheum Dis 1968;27:271-7.

36. Kaiser M, Weyand CM, Björnsson J, Goronzy JJ. Platelet-derived growth factor, intimal hyperplasia, and ischemic complications in giant cell arteritis. Arthritis Rheum 1998;41:623-33.

37. Ting KHJ, Lester S, Dunstan E, Hill CL. Association between histological features and clinical features of patients with biopsy positive giant cell arteritis. Clin Exp Rheumatol 2016;34(3 Suppl 97):S40-43.

38. Armstrong AT, Tyler WB, Wood GC, Harrington TM. Clinical importance of the presence of giant cells in temporal arteritis. J Clin Pathol 2008;61:669-71.

39. Mohammad AJ, Nilsson J-Å, Jacobsson LT, Merkel PA, Turesson C. Incidence and mortality rates of biopsy-proven giant cell arteritis in southern Sweden. Ann Rheum Dis 2014;76:993-7.

40. Jakobsson K, Jacobsson L, Mohammad AJ, et al. The effect of clinical features and glucocorticoids on biopsy findings in giant cell arteritis. BMC Musculoskelet Disord 2016;17:363.

41. Manjer J, Carlsson S, Elmståhl S, et al. The Malmö Diet and Cancer Study: representativity, cancer incidence and mortality in participants and non-participants. Eur $\mathrm{J}$ Cancer Prev Off $\mathrm{J}$ Eur Cancer Prev Organ ECP 2001;10:489-99.

42. Berglund G, Eriksson KF, Israelsson B, et al. Cardiovascular risk groups and mortality in an urban swedish male population: the Malmö Preventive Project. J Intern Med 1996;239:489-97.

43. Jakobsson $\mathrm{K}$, Jacobsson $\mathrm{L}$, Warrington $\mathrm{K}$, et al. Body mass index and the risk of giant cell arteritisresults from a prospective study. Rheumatol Oxf Engl 2015;54:433-40.

44. Hunder GG, Bloch DA, Michel BA, et al. The American College of Rheumatology 1990 criteria for the classification of giant cell arteritis. Arthritis Rheum 1990;33:1122-8.

45. Weyand CM, Wagner AD, Björnsson J, Goronzy JJ. Correlation of the topographical arrangement and the functional pattern of tissue-infiltrating macrophages in giant cell arteritis. J Clin Invest 1996;98:1642-9.

46. Samson M, Corbera-Bellalta M, Audia S, et al. Recent advances in our understanding of giant cell arteritis pathogenesis. Autoimmun Rev 2017;16:833-44.

47. Conway R, O'Neill L, McCarthy GM, et al. Interleukin 12 and interleukin 23 play key pathogenic roles in inflammatory and proliferative pathways in giant cell arteritis. Ann Rheum Dis 2018;77:1815-24.

48. Weyand CM, Tetzlaff N, Björnsson J, Brack A, Younge B, Goronzy JJ. Disease patterns and tissue cytokine profiles in giant cell arteritis. Arthritis Rheum 1997;40:19-26.

49. Graver JC, Boots AMH, Haacke EA, Diepstra A, Brouwer E, Sandovici M. Massive B-cell infiltration and organization into artery tertiary lymphoid organs in the aorta of large vessel giant cell arteritis. Front 
Immunol 2019;10:83.

50. Andersen JB, Myklebust G, Haugeberg G, Pripp AH, Diamantopoulos AP. Incidence trends and mortality of giant cell arteritis in southern Norway. Arthritis Care Res (Hoboken) 2020 published on Jan 7. doi:10.1002/acr.24133.

\section{Figures}

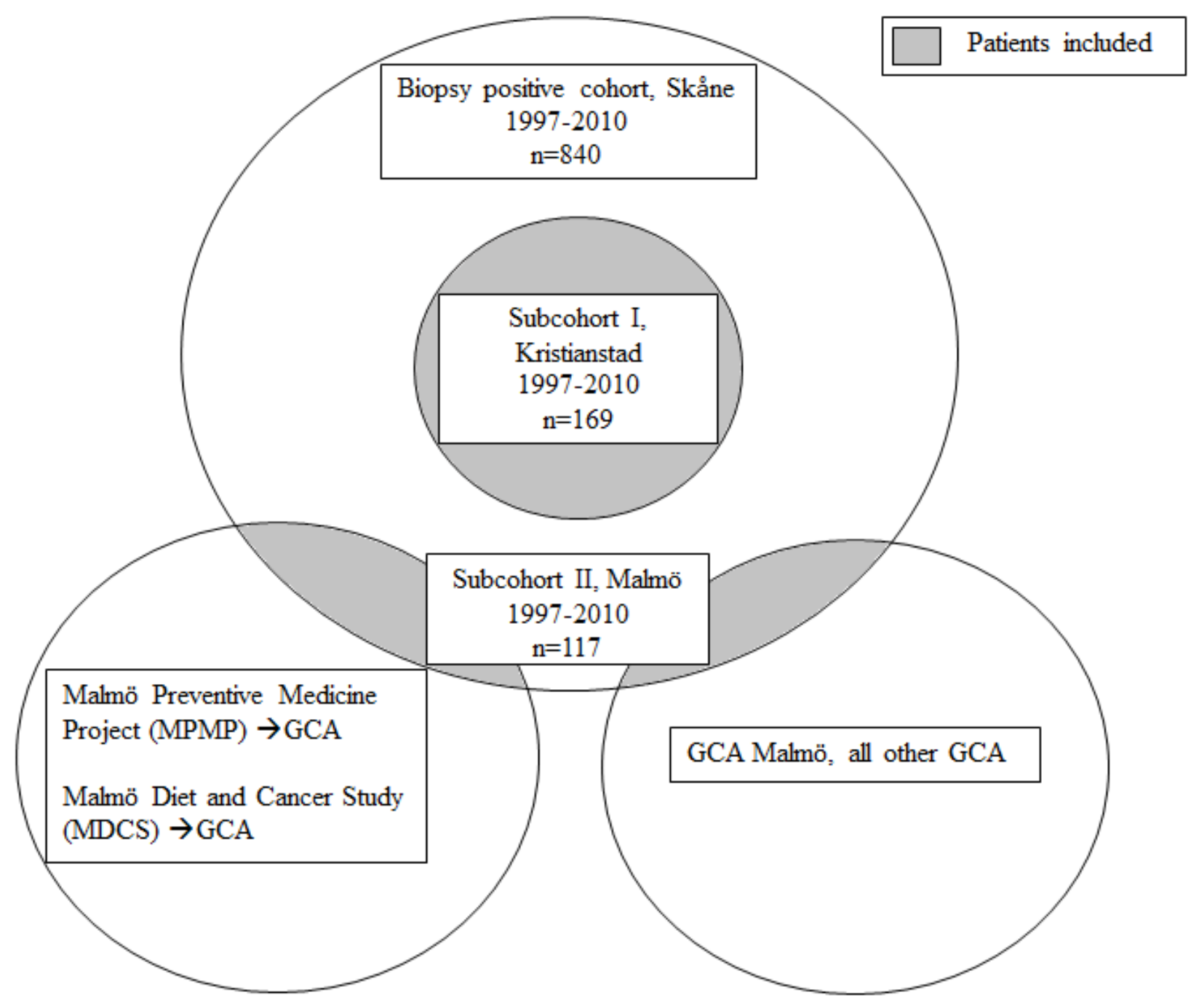

Figure 1

Study population, patient acquisition sources and identification process. Patients with positive temporal artery biopsy in the county of Skåne 1997-2010. Subcohort l: Patients registered at the pathology unit in Kristianstad. Subcohort II: Residents of the city of Malmö who participated in two health surveys and developed GCA, and other patients with biopsy-proven GCA from the city of Malmö. 


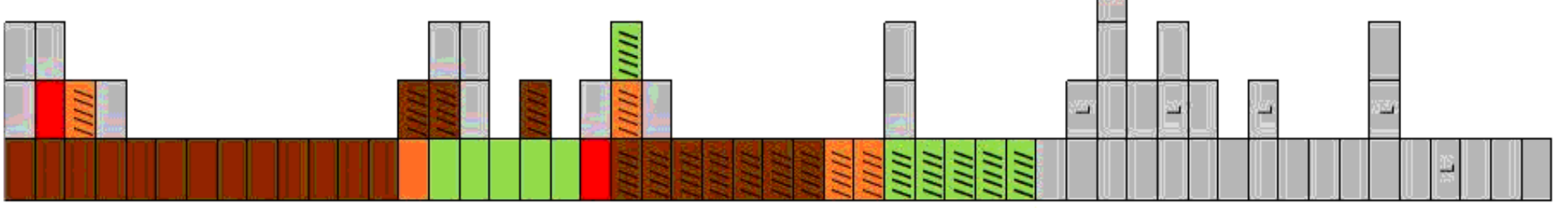

A. ascendens aneurysm

A. ascendens ectasia

A. descendens aneurysm

IIIIII A. descendens ectasia

A. abdominal aneurysm

////// A. abdominal ectasia

Dissection

Tributary involvement, L: lower leg arteries ( $\mathrm{nr}$ of squares equals $\mathrm{nr}$ of vessel beds involved)

Two patients with dissections, one with typA and another with typB

Figure 2

Distribution of involved vessels for each patient in the group of patients with giant cell arteritis with large vessel involvement (LVI). Each rectangle represents one vessel bed and each column represents one patient.

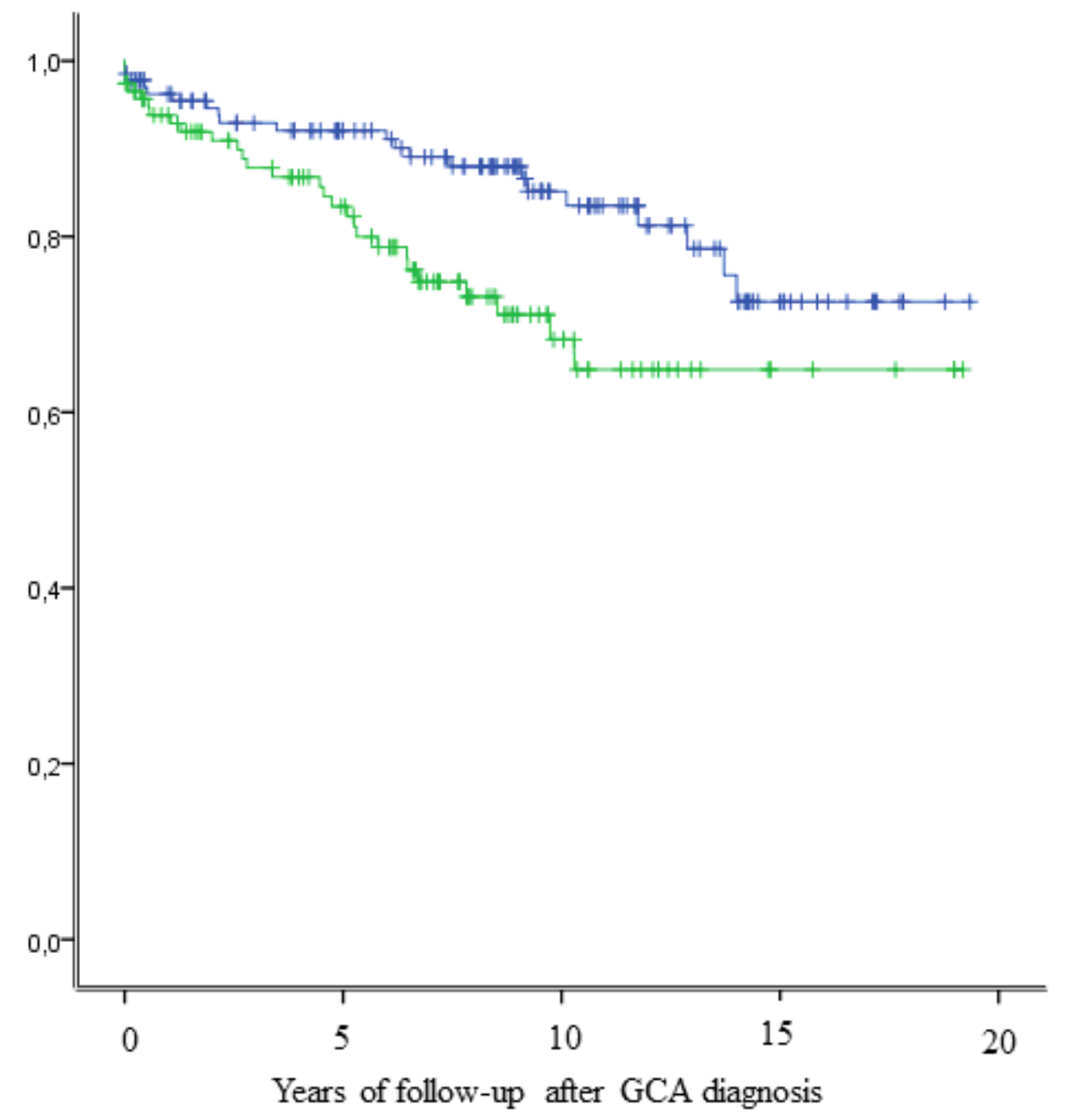

Giant cells

Present

Absent

$\mathrm{p}=0.014$ 


\section{Figure 3}

Survival free of large vessel involvement in patients with giant cell arteritis (GCA), by presence of giant cells in the temporal artery biopsy. Kaplan-Meier method. P-values based on Breslow's test. Vertical lines indicate patients censored. 